\section{ANALISIS PERLAKUAN AKUNTANSI ATAS PENDAPATAN PREMI DAN BEBAN KLAIM SESUAI PSAK NO. 28 PADA PT. ASURANSI ASTRA BUANA}

\author{
Christian Nataldy dan Robert Pius Pardede \\ Program Studi Akuntansi, Institut Bisnis dan Informatika Kesatuan \\ Bogor, Indonesia \\ Email:lemlit@stiekesatuan.ac.id
}

\begin{abstract}
The development of the insurance industry is currently undergoing quite good progress. Based on data from OJK, the insurance industry has experienced an average growth of $16 \%$ for the past 4 years. This can be seen from the progress in investment growth which reached $14.40 \%$ and premium growth of $21.00 \%$. This growth occurs because of the role of the insurance industry in serving the community to overcome risks. The insurance company will take the risk of the possibility that might occur to the community, such as loss or damage to the vehicle, fire, or the loss of natural disasters. The main source of insurance company income is from the sale of an insurance policy, which is in the form of insurance premiums given by the insured. And the insurance company's main burden is claim expense. Expenses incurred by insurance companies for reimbursement for a number of losses incurred by the insured.

The purpose of this study was to find out how the accounting treatment of premium income and claim expenses in accordance with PSAK No. 28 at PT. Asuransi Astra Buana/PT. AAB.

The results of the analysis of the accounting treatment of premium income and claim expenses at PT. AAB is in accordance with PSAK No. 28. Premium income is recognized and recorded at the time of issuance of the policy and presented in the financial statements in the form of gross premiums, premiums paid to reinsurers and a decrease (increase) in premiums which are not yet income. While claim expenses are recognized and recorded when the company arises to fulfill claims. Claim expenses are presented in the financial statements in the form of gross claims, reinsurance claims received from reinsurers and an increase (decrease) in estimated own retention claims. Compliance with PSAK No. 28 which has been carried out by PT. AAB needs to be maintained, in line with the developments in the PSAK, to avoid any errors in the recognition of premium income and claim expenses.
\end{abstract}

Key words : Premium Income and Claim Expenses

\title{
PENDAHULUAN
}

Kehadiran industri asuransi semakin hari semakin dirasakan oleh masyarakat dan pengusaha khususnya, karena peranannya yang semakin berkembang. Kemampuan perusahaan asuransi dalam melayani masyarakat mendapatkan apresiasi yang sangat tinggi dalam menanggulangi resiko. Adapun kondisi yang sering kita temui dalam dunia bisnis adalah pada saat suatu perusahaan manufaktur mengirimkan hasil produksinya kepada dealer atau customer. Selama perjalanan menuju gudang dealer maupun customer terdapat beberapa kemungkinan resiko yang mungkin terjadi, diantaranya pencurian, pembajakan maupun penggelapan oleh pihak ketiga atau perusahaan

Analisis

Perlakuan

Akuntansi atas

Pendapatan

Premi dan beban

klaim Sesuai

PSAK No. 28

pada PT.

Asuransi Astra

buana

258

Submitted:

MEI 2019

Accepted:

OKTOBER 2019

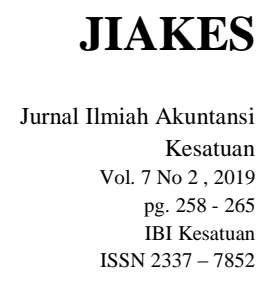




\section{Analisis \\ Perlakuan \\ Akuntansi atas \\ Pendapatan \\ Premi dan beban \\ klaim Sesuai \\ PSAK No. 28 \\ pada $P T$.}

Asuransi Astra

buana

ekspedisi. Disitulah peranan perusahaan asuransi untuk mengambil alih resiko yang dialami oleh perusahaan manufaktur.

Perusahaan asuransi harus mengganti sejumlah kerugian yang timbul atas hilangnya persediaan yang dicuri dalam perjalanan. Inilah yang disebut dengan istilah klaim. Klaim yang tertanggung terima merupakan sejumlah uang yang telah disepakati sebelumnya dalam kontrak asuransi. Kontrak asuransi merupakan suatu perjanjian yang dibuat antara tertanggung dan penanggung pada jangka waktu tertentu. Selama masa kontrak asuransi, tertanggung diwajibkan membayar premi atau tarif untuk perlindungan yang diberikan, besaran tarif ini ditetapkan oleh perusahaan asuransi dengan pertimbangan yang disesuaikan dengan kondisi tertanggung.

Dengan demikian dapat disimpulkan bahwa premi yang didapatkan oleh perusahaan asuransi merupakan penerimaan bagi perusahaan, dan klaim yang diberikan kepada tertanggung merupakan pengeluaran bagi perusahaan. Seperti selayaknya perusahaan pada umumnya, perusahaan asuransi pun dalam menjalankan operasionalnya berorientasi untuk menciptakan laba. Laba ini tercipta karena adanya selisih antara penerimaan perusahaan dengan pengeluaran perusahaan. Kemampuan perusahaan asuransi dalam menciptakan laba dalam suatu periode tertentu dilakukan dengan pengukuran yang tepat dan rasional, karena laba berisikan informasi yang sangat penting bagi berbagai pihak, baik internal maupun eksternal.

Dalam memberikan informasi yang tepat dan akurat terhadap laba yang dihasilkan, diperlukan adanya pengakuan dan pengukuran terhadap penerimaan perusahaan (premi) yang menjadi pendapatan perusahaan dan pengeluaran (klaim) yang menjadi beban perusahaan. Pengaruh yang diberikan akibat adanya perbedaan pengakuan pendapatan dan beban ini akan menjadi sangat luas saat berhubungan dengan laba, terutama dalam masalah perpajakan perusahaan yang menyebabkan laba yang dihasilkan lebih besar atau lebih kecil dibanding dengan yang seharusnya.

Perlakuan Akuntansi pada pendapatan dan beban ini harus dilandasi dengan Standar Akuntansi Keuangan yang berlaku umum dalam usaha asuransi kerugian yaitu PSAK 28, Standar akuntansi ini dibuat oleh Dewan Standar Akuntansi Keuangan (DSAK) untuk menjembatani Standar Akuntansi Keuangan lainnya dengan praktek akuntansi asuransi yang semakin berkembang di Indonesia.

Salah satu perusahaan asuransi terbesar di Indonesia adalah PT. Asuransi Astra Buana (AAB). PT. AAB ini merupakan perusahaan asuransi umum yang berdiri pada 12 September 1956. Semula PT. AAB ini bernama PT. Maskapai Asuransi Buana yang kemudian berganti nama seperti saat ini pada tahun 1990. Perusahaan ini mengawali usaha sebagai perusahaan asuransi kerugian. Perusahaan ini merupakan anak perusahaan Astra Group, dan banyak dipercaya oleh perusahaan astra group lainnya sebagai perusahaan asuransi untuk perusahaannya. Dengan nama besar Astra Group yang menaungi, perusahaan sangat disarankan untuk mampu bersaing dengan perusahaan lainnya dengan menerapkan PSAK 28 guna memenuhi standar dalam pelaporan keuangannya.

Beberapa perusahaan asuransi yang telah listing dalam Bursa Efek Indonesia telah menerapkan PSAK 28 dalam memenuhi standar pelaporan keuangannya, seperti yang telah diteliti oleh Yonathan Romoatn (2016) dalam penelitiannya yang berjudul Implementasi PSAK No. 62 Mengenai Kontrak Asuransi dan PSAK No. 28 (Revisi 2012) Tentang Akuntansi Kontrak Asuransi Kerugian (Studi Kasus PT. Asuransi Bina Dana Arta tbk) dan penelitian Aditya Indra Kusuma, Armanto Wicaksono (2014) yang berjudul Analisis Penerapan PSAK No. 62 Tentang Kontrak Asuransi dan PSAK No. 28 (Revisi 2012) Mengenai Akuntansi Asuransi Kerugian (Studi Kasus PT. Multi Artha Guna Tbk).

Berdasarkan uraian di atas, dirasakan perlu untuk melakukan penelitian yang terkait dengan PSAK No.28, dengan demikian penelitian ini akan difokuskan pada 

No. 28.

TINJAUAN PUSTAKA

Menurut Sensi (2006 : 25) asuransi kerugian adalah membantu menanggung resiko yang dipikul perusahaan, individu maupun perusahaan asuransi lain. Dan sebagai balas jasa, perusahaan asuransi kerugian, menerima premi sedangkan pihak tertanggung memperoleh perlindungan (protection) apabila terjadi atau mengalami suatu kerugian atau klaim.

Asuransi kerugian merupakan salah satu jenis usaha di bidang asuransi yang khusus bergerak dalam pertanggungan atas kemungkinan kerugian harta kekayaan atau property yang mungkin dapat menimpa tertanggung. Setelah perusahaan asuransi kerugian menerima premi, berarti perusahaan tersebut menerima resiko-resiko yang dipertanggungkan kepadanya, sebagai tanda bukti telah mengeluarkan polis asuransi.

Proses akuntansi yang baik sangat mutlak harus dimiliki oleh setiap perusahaan asuransi, sesuai dengan prinsip going concern. Banyak pihak yang memiliki keterkaitan langsung dengan perusahaan harus dapat menjaga kepercayaan pemakai jasa dengan memanfaatkan sumber daya yang ada pada perusahaan. Beberapa pihak yang memiliki kepentingan dalam perusahaan atau industri asuransi menurut Sensi (2006) antara lain :

1. Pimpinan Perusahaan (Management)

2. Pemegang Saham (Pemilik Perusahaan)

3. Pemegang Polis (Tertanggung)

4. Reasuradur (Reinsurer)

5. Agen (Broker)

6. Pemerintah (Fiskus)

Di Indonesia standar akuntansi yang berlaku umum dan digunakan dalam industri asuransi kerugian adalah :

1. Pernyataan Standar Akuntansi Keuangan (PSAK) No. 28 tentang Akuntansi Kontrak Asuransi Kerugian dan PSAK No. 62 mengenai Kontrak Asuransi yang diterbitkan Ikatan Akuntansi Indonesia.

2. Pedoman Akuntansi Kerugian (PAKASI-Kerugian) yang diterbitkan oleh Dewan Asuransi Indonesia (DAI) bekerjasama dengan Direktorat Asuransi, Direktorat Lembaga Keuangan, Departemen Keuangan.

Menurut PSAK 28 (Revisi 2012), pendapatan premi yang diperoleh sehubungan dengan kontrak asuransi dan reasuransi diakui sebagai pendapatan selama periode polis (kontrak), berdasarkan proporsi jumlah proteksi yang diberikan. Premi yang diperoleh perusahaan dari tertanggung diakui dan dicatat menggunakan prinsip akrual basis, yaitu diakui dan dicatat langsung pada saat terjadi transaksi.

Premi reasuransi yang dibayarkan kepada reasuransi diakui dan dicatat perusahaan pada periode yang sama dengan periode pengakuan pendapatan premi yang diperoleh dari tertanggung (premi bruto) yang bersangkutan. Premi reasuransi ini diakui perusahaan sebagai beban yang pada akhir tahun akan mengurangi pendapatan premi bruto. Pengakuan dan pencatatan atas premi yang diperoleh perusahaan yaitu jumlah premi dibayar atau bagian premi atas transaksi reasuransi prospektif diakui sebagai premi reasuransi selama sisa periode kontrak yang jumlahnya proporsional dengan proteksi yang diberikan.

Untuk cadangan premi yang dianggap sebagai premi yang belum merupakan pendapatan selama tahun berjalan, perusahaan mengakui dan mencatatnya pada akhir tahun, karena cadangan premi tahun yang lalu sudah diakui sebagai pendapatan untuk 


\begin{tabular}{l} 
Analisis \\
Perlakuan \\
Akuntansi atas \\
Pendapatan \\
Premi dan beban \\
klaim Sesuai \\
PSAK No. 28 \\
pada PT. \\
Asuransi Astra \\
buana \\
\\
$\mathbf{2 6 1}$ \\
\hline
\end{tabular}

Analisis

Perlakuan

Akuntansi atas

Pendapatan

Premi dan beban

klaim Sesuai

PSAK No. 28

pada $P T$.

Asuransi Astra

$\underline{261}$

tahun berjalan maka cadangan premi tersebut harus dikurangkan dari cadangan premi tahun berjalan. Hal ini menimbulkan adanya penurunan atau kenaikan dari cadangan premi sebagai penambah atau pengurang dari premi bruto. Dalam laporan laba rugi, premi asuransi disajikan sebagai premi bruto (gross premium), dikurangi dengan premi reasuransi kepada reasuradur, serta ditambah (dikurangi) kenaikan (penurunan) cadangan premi.

Pengakuan dan pencatatan beban menurut PSAK No. 28 dimana dinyatakan bahwa beban klaim diakui dan dicatat bersamaan dengan timbulnya kewajiban kepada tertanggung pada periode terjadinya peristiwa yang mungkin mengakibatkan kerugian bagi tertanggung dimana besarnya beban klaim, diperhitungkan berdasarkan taksiran ganti rugi yang belum diselesaikan termasuk ganti rugi untuk klaim yang belum dilaporkan pada akhir tahun. Taksiran ini mencerminkan jumlah klaim yang dicadangkan pada akhir tahun yang mungkin akan menimbulkan beban pada periode yang akan datang, perusahaan mencatat ini sebagai cadangan klaim.

Menurut PSAK No. 28, cadangan klaim, diakui sebagai estimasi klaim tanggungan (retensi) sendiri yang mengandung arti sebenarnya. Maksudnya taksiran tersebut meliputi klaim yang telah terjadi tetapi belum dibayar, klaim yang masih dalam proses penyelesaian, klaim yang telah terjadi tetapi belum dilaporkan serta biaya penyelesaian atas klaim-klaim tersebut dimana di dalamnya telah dikurangkan dengan bagian yang menjadi tanggungan reasuradur. Kenaikan atau penurunan cadangan klaim yang diakui perusahaan pada akhir periode akuntansi merupakan penambah atau pengurang beban klaim (klaim bruto). Cadangan klaim dicatat langsung pada saat ada laporan klaim dari tertanggung. Penyajian beban klaim pada laporan laba rugi adalah klaim bruto dikurangi dengan klaim reasuransi, serta ditambah (dikurangi) kenaikan (penurunan) cadangan klaim.

\section{METODE PENELITIAN}

Metode analisis data yang digunakan dalam penelitian ini adalah deskriptif kualitatif, yaitu dengan menganalisa data yang diperoleh dalam penelitian, menguraikan secara deskriptif hasil penelitian serta mengambil simpulan. Teknik pengumpulan data yang digunakan dalam penelitian ini adalah sebagai berikut:

1. Wawancara dilakukan dengan bagian accounting untuk memperoleh data tentang penerapan dan pengakuan pendapatan premi dan beban klaim sesuai PSAK No. 28

2. Dokumentasi diperoleh data tentang sejarah singkat perusahaan, struktur organisasi perusahaan, tujuan perusahaan dan laporan keuangan perusahaan.

3. Observasi langsung, pengumpulan data dengan cara mengamati secara langsung sumber data yang dianalisis, kemudian diuraikan dalam data tertulis.

\section{HASIL DAN PEMBAHASAN}

Dari hasil penelitian yang telah dilakukan, diketahui bahwa perusahaan telah menerapkan PSAK 28. Hal tersebut terlihat dari pengakuan dan pengukuran pendapatan premi dan beban klaim perusahaan. Pendapatan premi terbagi menjadi 3 bagian, yaitu premi bruto, premi reasuransi dan kenaikan (penurunan) premi yang belum merupakan pendapatan. Pendapatan premi bersih asuransi didapat dari total pendapatan premi bruto dikurangi dengan premi reasuransi kemudian dikurangi (ditambah) kenaikan (penurunan) premi yang belum merupakan pendapatan. Pengakuan pendapatan premi yang diperoleh sehubungan dengan kontrak asuransi diakui sebagai pendapatan selama periode polis (kontrak) berdasarkan proporsi jumlah proteksi yang diberikan. 
Premi bruto yang diperoleh, diakui sebagai pendapatan berdasarkan akrual basis, yang berarti apabila adanya penerbitan polis tetapi pembayaran premi belum diterima, maka perusahaan telah mengakui adanya pendapatan atas polis tersebut.

Jurnal yang dicatat perusahaan pada saat mengakui premi bruto yaitu:

1. Saat perusahaan telah menerbitkan polis asuransi, maka jurnalnya sebagai berikut:

\begin{tabular}{|l|c|c|}
\hline \multicolumn{1}{|c|}{ Nama Akun } & Debit & Kredit \\
\hline Piutang Premi & $\mathrm{xxx}$ & \\
\hline Pendapatan premi & & $\mathrm{xxx}$ \\
\hline
\end{tabular}

2. Saat perusahaan menerima pembayaran premi dari nasabah, maka jurnalnya sebagai berikut:

\begin{tabular}{|l|c|c|}
\hline \multicolumn{1}{|c|}{ Nama Akun } & Debit & Kredit \\
\hline Kas & $\mathrm{xxx}$ & \\
\hline Piutang Premi & & $\mathrm{xxx}$ \\
\hline
\end{tabular}

Premi reasuransi merupakan bagian dari premi bruto yang menjadi hak reasuradur berdasarkan perjanjian sebelumnya. Peran reasuradur sendiri sebagai perusahaan reasuransi untuk menanggung resiko yang mungkin timbul dari perusahaan asuransi yang telah mengadakan perjanjian kerjasama. Premi reasuransi yang dibayarkan kepada reasuradur diakui dan dicatat pada periode yang sama dengan periode pengakuan pendapatan premi yang diperoleh dari tertanggung (premi bruto) yang bersangkutan.

Premi reasuransi ini diakui sebagai beban yang pada akhir tahun akan mengurangi pendapatan premi bruto. Pengakuan dan pencatatan atas premi yang diperoleh yaitu jumlah premi dibayar atau bagian premi atas transaksi reasuransi prospektif diakui sebagai premi reasuransi selama sisa periode kontrak yang jumlahnya proporsional dengan proteksi yang diberikan. berikut :

Adapun jurnal yang dicatat pada saat pembayaran premi ke reasuradur sebagai

\begin{tabular}{|l|c|c|}
\hline \multicolumn{1}{|c|}{ Nama Akun } & Debit & Kredit \\
\hline Premi Reasuransi & $\mathrm{xxx}$ & \\
\hline Kas/Bank & & $\mathrm{xxx}$ \\
\hline
\end{tabular}

Cadangan atas premi yang belum merupakan pendapatan merupakan bagian dari pendapatan yang telah dilunasi namun belum merupakan pendapatan karena pada akhir periode, pertanggungan masih berjalan. Perusahaan mengakui dan mencatat premi yang belum merupakan pendapatan pada akhir periode sebagai pengurang dari pendapatan premi yang dihitung secara individual dari tiap pertanggungan yang besarnya ditetapkan secara proporsional terhadap jumlah proteksi yang diberikan selama periode pertanggungan.

Jurnal yang dicatat untuk menyesuaikan cadangan premi yang belum merupakan pendapatan sebagai berikut :

\begin{tabular}{|c|c|c|c|}
\hline Nama Akun & & Debit & Kredit \\
\hline Cadangan Premi (CAPYBMP) & & $\mathrm{XXX}$ & \\
\hline Penurunan & Premi & & $\mathrm{XXX}$ \\
\hline
\end{tabular}


Analisis

Perlakuan

Akuntansi atas

Pendapatan

Premi dan beban

klaim Sesuai

PSAK No. 28

pada $P T$.

Asuransi Astra

buana

263

Beban klaim merupakan beban khusus dalam perusahaan asuransi yang perlakuannya berbeda dengan beban lainya. Klaim dan manfaat asuransi meliputi klaimklaim yang telah disetujui (settled claim), klaim dalam proses penyelesaian (outstanding claim), dan klaim yang terjadi namun belum dilaporkan (claim incurred but not yet reported/IBNR).

Beban Klain yang diakui terbagi kedalam 3 bagian, yaitu klaim bruto, klaim reasuransi dan penurunan (kenaikan) estimasi klaim retensi sendiri.

Beban Klaim meliputi klaim bruto. Klaim bruto adalah klaim yang dikeluarkan atas pertanggungan yang diberikan kepada tertanggung. Klaim bruto ini termasuk didalamnya biaya-biaya lain yang dikeluarkan perusahaan dalam memberikan klaim pertanggungan, seperti biaya survey klaim dan biaya penyelesaian klaim. Perusahaan mengakui klaim bruto pada saat timbulnya liabilitas untuk memenuhi klaim tersebut.

Jurnal yang dicatat untuk mengakui klaim bruto nasabah sebagai berikut :

1. Saat perusahaan mengakui adanya klaim dari nasabah :

\begin{tabular}{|l|c|c|}
\hline \multicolumn{1}{|c|}{ Nama Akun } & Debit & Kredit \\
\hline Beban Klaim & xxx & \\
\hline Hutang Klaim & & xxx \\
\hline
\end{tabular}

2. Saat perusahaan membayar klaim kepada nasabah :

\begin{tabular}{|l|c|c|}
\hline \multicolumn{1}{|c|}{ Nama Akun } & Debit & Kredit \\
\hline Hutang Klaim & $\mathrm{xxx}$ & \\
\hline Kas & & $\mathrm{xxx}$ \\
\hline
\end{tabular}

Klaim reasuransi merupakan bagian dari klaim bruto yang merupakan tanggung jawab reasuradur berdasarkan perjanjian antara perusahaan asuransi dengan perusahaan reasuradur. Disinilah perananan dari reasuradur sebagai perusahaan yang menaggulangi resiko perusahaan asuransi untuk menggantikan senilai klaim berdasarkan proporsi yang telah disepakakti sebelumnya.

Klaim reasuransi yang diakui dan dicatat pada periode yang sama dengan periode pengakuan klaim bruto yang diberikan kepada tertanggung yang bersangkutan. Klaim reasuransi ini diakui sebagai pengurang dari klaim bruto pada akhir periode. Pengakuan klaim reasuransi ini dicatat sebesar klaim selama periode kontrak yang jumlahnya proporsional.

Jurnal untuk mencatat pengakuan adanya klaim reasuransi ke reasuradur :

\begin{tabular}{|l|c|c|}
\hline \multicolumn{1}{|c|}{ Nama Akun } & Debit & Kredit \\
\hline Piutang Reasuransi & $\mathrm{xxx}$ & \\
\hline Klaim Reasuransi & & $\mathrm{xxx}$ \\
\hline
\end{tabular}

Jurnal untuk mencatat saat klaim reasuransi diterima :

\begin{tabular}{|l|c|c|}
\hline \multicolumn{1}{|c|}{ Nama Akun } & Debit & Kredit \\
\hline Kas & $\mathrm{xxx}$ & \\
\hline
\end{tabular}




\begin{tabular}{|l|c|c|}
\hline $\begin{array}{l}\text { Piutang } \\
\text { Reasuransi }\end{array}$ & & $\mathrm{xxx}$ \\
\hline
\end{tabular}

Estimasi klaim retensi sendiri merupakan taksiran jumlah kewajiban yang menjadi tanggungan sendiri sehubungan dengan klaim yang masih dalam proses penyelesaian, termasuk klaim yang terjadi namun belum dilaporkan. Perusahaan mengakui estimasi klaim retensi sendiri pada akhir periode sebagai penambah atau pengurang dari klaim bruto. Sehubungan dengan namanya, jumlahnya hanya estimasi atas klaim yang masih dalam proses penyelesaian maupun atas klaim yang terjadi namun belum dilaporkan.

Jurnal yang dicatat untuk menyesuaikan cadangan premi yang belum merupakan pendapatan sebagai berikut :

\begin{tabular}{|l|l|c|}
\hline \multicolumn{1}{|c|}{ Nama Akun } & Debit & Kredit \\
\hline $\begin{array}{l}\text { Cadangan Klaim } \\
\text { (Estimasi Klaim) }\end{array}$ & xxx & \\
\hline $\begin{array}{l}\text { Kenaikan } \\
\text { Cadangan Klaim }\end{array}$ & & xxx \\
\hline
\end{tabular}

\author{
Analisis \\ Perlakuan \\ Akuntansi atas \\ Pendapatan \\ Premi dan beban \\ klaim Sesuai \\ PSAK No. 28 \\ pada $P T$. \\ Asuransi Astra \\ buana
}

\title{
SIMPULAN
}

1. Perusahaan mengakui pendapatan premi berdasarkan prinsip akrual basis, dimana pendapatan premi diakui pada saat polis asuransi diterbitkan, yang dicatat sebagai premi bruto perusahaan. Dan mengakui adanya premi yang dibayarkan kepada reasuradur dan mencatatnya sebagai pengurang dari premi bruto perusahaan dan menghitung adanya penurunan (kenaikan) premi yang belum merupakan pendapatan untuk diakui dan dicatat sebagai penambah (pengurang) pendapatan premi perusahaan tahun berjalan. Beban klaim diakui dan dicatat pada saat timbulnya kewajiban perusahaan untuk membayar sejumlah uang atas klaim tertanggung. Perusahaan mengakui klaim yang diterima langsung dari tertanggung sebagai klaim bruto perusahaan dan mengakui adanya klaim reasuransi yang diterima dari reasuradur dan mencatat sebagai pengurang klaim bruto perusahaan. Serta menghitung adanya kenaikan (penurunan) estimasi klaim retensi sendiri untuk mengakui dan mencatat sebagai penambah (pengurang) beban klaim perusahaan pada tahun berjalan.

2. Dari analisis yang telah dilakukan, perusahaan telah menerapkan PSAK No.28 secara keseluruhan dalam mengakui dan melaporkan pendapatan premi dan beban klaim perusahaan asuransi.

3. Pada laporan laba rugi komperehensif, perusahaan menyajikan pendapatan premi perusahaan terdiri atas premi bruto yang merupakan hasil penjualan polis perusahaan dikurangi dengan premi reasuransi yang dibayarkan kepada pihak reasuradur sebagai haknya reasuradur, kemudian dikurangi kenaikan premi yang belum merupakan pendapatan perusahaan pada periode berjalan. Perusahaan juga menyajikan beban klaimnya terdiri atas klaim bruto perusahaan dikurangi dengan klaim reasuransi yang menjadi kewajiban reasuradur dan ditambah dengan kenaikan estimasi klaim retensi sendiri. Penyajian laporan laba rugi ini telah sesuai dengan penyajian laporan laba rugi perusahaan asuransi kerugian menurut PSAK No. 28.

\section{DAFTAR PUSTAKA}




Analisis
Perlakuan
Akuntansi atas
Pendapatan
Premi dan beban
klaim Sesuai
PSAK No. 28
pada PT.
Asuransi Astra
buana

$\mathbf{2 6 5}$

Darmawi, Herman. 2004. Manajemen Asuransi. Bumi Aksara. Jakarta

Ikatan Akuntan Indonesia. 2015. Standar Akuntansi Keuangan. Salemba Empat, Jakarta.

Kasmir. 2014. Bank dan Lembaga Keuangan Lainnya, Edisi Revisi 2014, Raja Grafindo Persada, Jakarta.

Kitab Undang-Undang Hukum Dagang Tentang Asuransi atau Pertanggungan Seumurnya, Bab 9, Pasal 246.

Kusuma, Aditya Indra dan Armanto Wicaksono. 2014. Analisis Penerapan PSAK No. 62 Tentang Kontrak Asuransi dan PSAK No. 28 (Revisi 2012) Mengenai Akuntansi Asuransi Kerugian (Studi Kasus PT. Multi Artha Guna Tbk). Jurnal Ilmiah. Universitas Bina Nusantara. Jakarta.

Martono dan Agus Harjito. 2010. Manajemen Keuangan. Ekonisia. Yogyakarta.

Nitisusastro, M. 2013. Asuransi dan Usaha Perasuransian di Indonesia. Alfabeta, Bandung.

Purba, Radiks. 2002. Asuransi Indonesia. Salemba Empat. Jakarta.

Romoatn, Yonathan. 2016. Implementasi PSAK No. 62 Mengenai Kontrak Asuransi dan PSAK No. 28 (Revisi 2012) Tentang Akuntansi Kontrak Asuransi Kerugian (Studi Kasus PT. Asuransi Bina Dana Arta tbk). Jurnal Ilmiah. STIE Widya Dharma. Pontianak.

Rosalie, Eugenia dan Novi S. Budiarso. 2016. Analisis Pengakuan Pendapatan dan Beban Menurut PSAK No. 28 Pada PT. Asuransi Tri Pakarta Cabang Manado. Jurnal Ilmiah. Universitas Sam Ratulangi. Manado.

Sensi W, Ludovicus. 2006. Memahami Akuntansi Asuransi Kerugian. PT. Prima Mitra Edukarya. Jakarta.

Soemarso Syafri Harahap. 2008. Analisa Kritis atas Laporan Keuangan, PT. Raja Grafindo Persada, Jakarta.

Wardiyah, M.L. 2016. Akuntansi Keuangan Menengah. CV Pustaka Setia, Bandung. 